\title{
An updated infrageneric classification of the oaks: review of previous taxonomic schemes and synthesis of evolutionary patterns
}

\section{Thomas Denk ${ }^{1}$, Guido W. Grimm², Paul S. Manos $^{3}$, Min Deng ${ }^{4} \&$ Andrew Hipp ${ }^{5,6}$}

${ }^{1}$ Swedish Museum of Natural History, Box 50007, 10405 Stockholm, Sweden

${ }^{2}$ Unaffiliated, 45100 Orléans, France

${ }^{3}$ Duke University, Durham NC 27708, USA

${ }^{4}$ Shanghai Chenshan Plant Science Research Center, Chinese Academy of Sciences, Shanghai 201602, China

5 The Morton Arboretum, Lisle IL 60532-1293, USA

${ }^{6}$ The Field Museum, Chicago IL 60605, USA

In this paper, we review major classification schemes proposed for oaks by John Claudius Loudon, Anders Sandøe Ørsted, William Trelease, Otto Karl Anton Schwarz, Aimée Antoinette Camus, Yuri Leonárdovich Menitsky, and Kevin C. Nixon. Classifications of oaks (Fig. 1) have thus far been based entirely on morphological characters. They differed profoundly from each other because each taxonomist gave a different weight to distinguishing characters; often characters that are homoplastic in oaks. With the advent of molecular phylogenetics our view has considerably changed. One of the most profound changes has been the realisation that the traditional split between the East Asian subtropical to tropical subgenus Cyclobalanopsis and the subgenus Quercus that includes all other oaks is artificial. The traditional concept has been replaced by that of two major clades, each comprising three infrageneric groups: a Palearctic-Indomalayan clade including Group Ilex (Ilex oaks), Group Cerris (Cerris oaks) and Group Cyclobalanopsis (cycle-cup oaks), and a predominantly Nearctic clade including Group Protobalanus (intermediate or golden cup oaks), Group Lobatae (red oaks) and Group Quercus (white oaks, with most species in America and some 30 species in Eurasia). The main morphological feature characterising these phylogenetic lineages is pollen morphology, a character overlooked in traditional classifications. This realisation, along with the now available (molecular-)phylogenetic framework, opens new avenues for biogeographic, ecological and evolutionary studies and a re-appraisal of the fossil record. We provide an overview about recent advances in these fields and outline how the results of these studies contribute to the establishment of a unifying systematic scheme of 
oaks. Ultimately, we propose an updated classification of Quercus recognising two subgenera with eight sections. This classification considers morphological traits, molecular-phylogenetic relationships, and the evolutionary history of one of the most important temperate woody plant genera.

\section{Part A. History of classifications of oaks}

In his original work, Carl von Linné listed 14 species of oaks from Europe and North America: the white oaks Q. alba, Q. cesculus (= Q. petraea (Matt.) Liebl.), Q. robur, and Q. prinus (status unresolved); the red oaks Q. rubra, Q. nigra, and Q. phellos; the Cerris oaks $Q$. cerris, Q. cegilops (= Q. macrolepis Kotschy), Q. suber; and the Ilex oaks Q. ilex, Q. coccifera, Q. gramuntia (= Q. ilex), and Q. smilax (= Q. ilex) (Linné 1753). This number had increased to 150 species when Loudon $(1838,1839)$ provided the first infrageneric classification of oaks recognising ten sections based on reproductive and leaf characters. Eight of Loudon's sections (Albce, Prinus, Robur; Nigrce, Phellos, Rubrc; Cerris; Ilex) were based on species described by Linné (Fig. 1). New additions were the (fully) evergreen southeastern North American "Live Oaks", sect. Virentes; and the "Woolly-leaved Oaks", sect. Lanatce, of Nepal (including an Ilex oak and a species that was later recognised as a cycle-cup oak). Loudon's classification is remarkable in one aspect: he established the fundamental subdivision of European oaks (his sections Cerris, Ilex, and Robur). This subdivision, although modified, occurs in nearly all later classifications and corresponds to clades in most recent molecular-phylogenetic trees (cerroid, ilicoid, and roburoid oaks; cf. Denk and Grimm 2010; A. Hipp and co-workers, work in progress).

Ørsted (1871) can be credited for recognising an important Asian group of oaks hardly known at the time of Loudon and originally associated with Cyclobalanus (=Lithocarpus): the cyclecup oaks of subtropical and tropical East Asia, which Ørsted considered distinct from Quercus as genus Cyclobalanopsis, within his subtribe Quercinae (Fig. 1). This concept was adopted by later researchers (e.g. Camus 1936-1938; Nixon 1993; as subgenera) and is still used for the Flora of China (Huang et al. 1999; Flora of China 2016). Within the second genus of the Quercinae, Quercus, Ørsted recognised five subgenera with a total of 16 sections and about 184 species. His work is the first to treat oaks in a global context; Loudon, and later Camus, Trelease, and Menitsky, treated the Nearctic and Palearctic-Indomalayan taxa independently. 
Subgenus Cerris

Sect.
Cyclobalan.
Sect.
Cerris

Subgenus

Cyclobalanopsis

\section{New classification}

\section{Subgenus Quercus}

\begin{tabular}{|ccc}
\hline $\begin{array}{c}\text { Sect. } \\
\text { Quercus } \\
\text { Ponticae }\end{array}$ Sect. \\
Virentes
\end{tabular} Sect. $\begin{gathered}\text { Sect. } \\
\text { Lobatae }\end{gathered}$ Protobalanus

Nixon (1993)

Subgenus Quercus
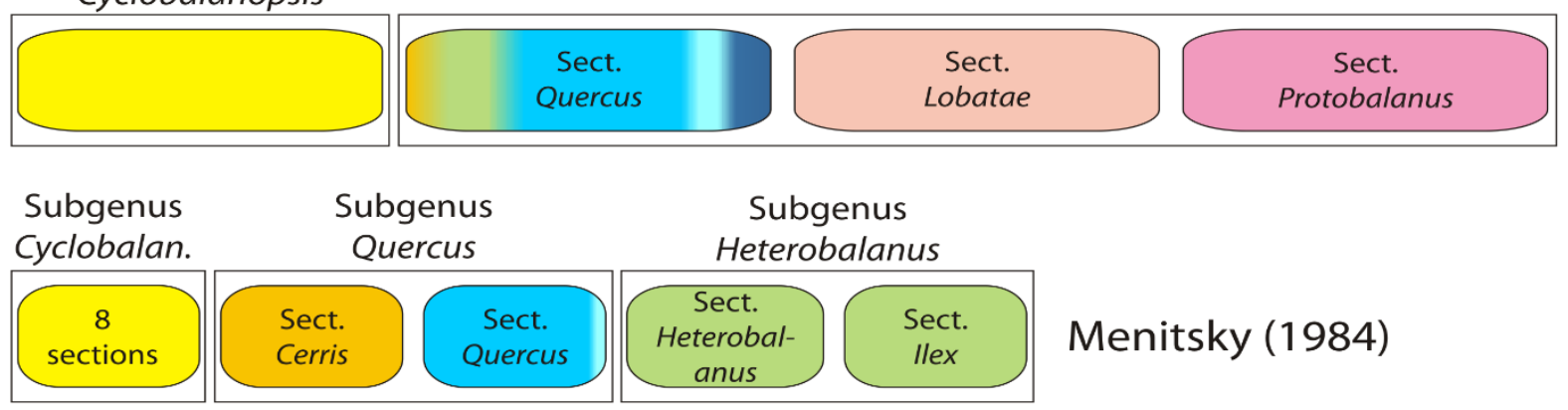

Heterobalanus

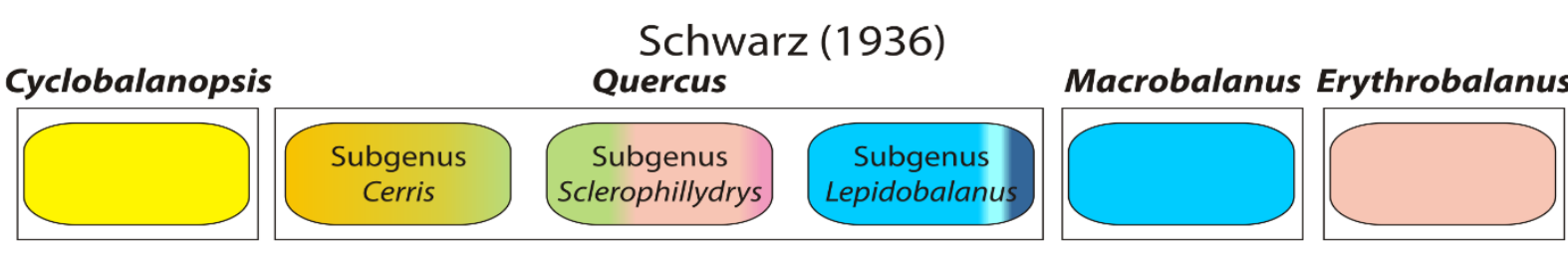

Menitsky (1984)

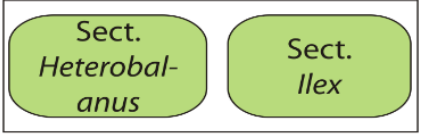

Schwarz (1936) rcus

\section{Camus (1936-1954)}

Subgenus Cyclobalanopsis
Subgenus Euquercus

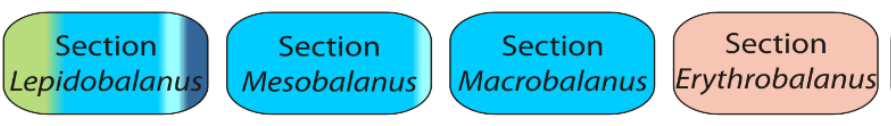

Section Protobalanus

\section{Trelease (1924)}
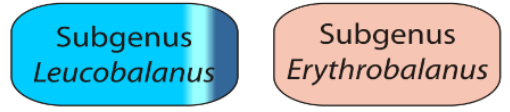

Subgenus Protobalanus

Cyclobalanopsis

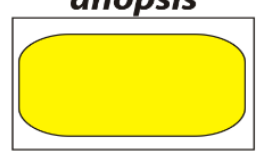

Ørsted (1871)

Quercus

\begin{tabular}{|c|c|c|c|c|}
\hline $\begin{array}{l}\text { Subgenus } \\
\text { Cerris }\end{array}$ & $\begin{array}{c}\text { Subgenus } \\
\text { Heterobalanus }\end{array}$ & $\left(\begin{array}{c}\text { Subgenus } \\
\text { Lepidobalanus }\end{array}\right)$ & $\begin{array}{c}\text { Subgenus } \\
\text { Macrobalanus }\end{array}$ & $\begin{array}{l}\text { Subgenus } \\
\text { Erythrobalanus }\end{array}$ \\
\hline
\end{tabular}

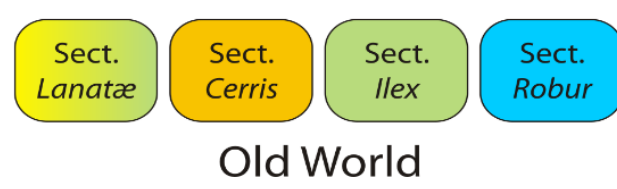

Loudon (1838)

Figure 1: Classification schemes for Quercus from Loudon to Nixon (see Appendix).

Colour coding denotes the actual systematic affiliation of species included in each taxon: of the 'Old World' or 'mid-latitude clade' section Cyclobalanopsis (cycle-cup oaks, yellow), section Cerris (Cerris oaks; orange), and section Ilex (llex oaks; green); and of the 'New World' or 'high-latitude clade' section Quercus (white oaks s.str.; blue), sections Virentes (cyan) and Ponticae (dark blue), section Protobalanus (intermediate oaks; purple), and section Lobatae (red oaks; red). Colour gradients are proportional, i.e. reflect the proportion of species with different systematic affiliation included in each taxon. Note: Menitsky (1984) and Trelease (1924) only treated the Eurasian and American oaks, respectively, and provided classifications in (nearly) full agreement with current phylogenies. 
In the early $20^{\text {th }}$ century, two competing classification concepts emerged, which were henceforth used by researchers (partly until today). The central/eastern European tradition followed in principle the classification system of Schwarz (1936), whereas the western/southern European tradition relied on the monographic work of Camus (1936-1938, 1938-1939, 1952-1954). A decade earlier, Trelease (1924) provided a comprehensive treatment of the North American oaks listing about 371 species (nearly half of them new) in 138 series and three subgenera/sections (Fig. 1): Leucobalanus (white oaks), Erythrobalanus (red oaks), and Protobalanus (intermediate oaks). Thus, he established the still valid tripartition of the genus in North America (sections Quercus, Lobatae, Protobalanus; (Jensen 1997; Manos 1997; Nixon and Muller 1997). Camus and Schwarz (partly) followed Trelease regarding the classification of North American oaks, but disagreed with respect to the oaks of Eurasia and North Africa, specifically on how to classify the North American oaks in relation to their Eurasian counterparts. Camus followed Ørsted's general scheme, but recognised a single genus Quercus with the two subgenera Cyclobalanopsis and Quercus. She downgraded Ørsted's subgenera in Quercus to sections (Fig. 1). Schwarz (1936) also followed in principle the concepts of Ørsted, but raised Ørsted's categories, erecting a two-tribe system (Cyclobalanopsideae, Querceae) with two genera each (Cyclobalanopsis + Erythrobalanus, Macrobalanus + Quercus). A novelty in the system of Schwarz was the subgenus Sclerophyllodrys (Fig. 1), in which he accommodated many sclerophyllous oaks of Eurasia, Trelease's subgenus Protobalanus (including an Asian series Spathulatae), and six evergreen series of Trelease's subgenus Erythrobalanus. Another major difference relative to Camus was that Schwarz adopted Ørsted's global concept by grouping North American and Eurasian white oaks in the same sections (Dascia, Gallifera, Prinus, Roburoides).

The most recent monographic work towards a new classification of oaks was the one of Menitsky (1984, translated into English in 2005) dealing with Asian oaks (Fig. 1). Except for a single species (Q. suber), Menitsky placed all Ilex oaks in subgenus Heterobalanus, while Cerris oaks (except for Q. suber) formed one of the two sections in subgenus Quercus (the other section included the white oaks). Menitsky's account is the only morphology-based system that correctly identified the natural groups of Eurasian oaks confirmed later by palynological and molecular data. In the same way, Trelease's sections of North American oaks also have been confirmed as natural groups.

The latest and currently most widely used (e.g. Govaerts and Frodin 1998; see also www.wikipedia.org and www.internationaloaksociety.org) classification is by Nixon (1993), 4 
published as a review. Nixon adopted the concept of Camus but merged her sections Cerris, which comprised Cerris and Ilex oaks, and Euquercus, comprising the remaining Ilex oaks and the white oaks, into a single section Quercus. According to this latest modification of Ørsted's more than 150 years old scheme, the genus Quercus is divided into two subgenera, the cycle-cup oaks (Cyclobalanopsis) and all remaining oaks (Quercus). Subgenus Quercus includes two natural sections, one comprising the red oaks (sect. Lobatae) and one comprising the intermediate oaks (sect. Protobalanus), and a heterogeneous, artificial, northern hemispheric section Quercus including all white oaks, Cerris and Ilex oaks (Fig. 1).

\section{Change in criteria for classification}

There are two major causes for the differences in the traditional, morphology-based classifications of oaks: 1) the weighing of morphological characters, 2) the geographic regions considered. Convergent morphological evolution is a common phenomenon in the genus Quercus and the Fagaceae in general (Oh and Manos 2008; Kremer et al. 2012). For instance, Loudon's (1838) descriptions for the distantly related sections Ilex (Eurasian Q. ilex and relatives) and Virentes (North American Q. virens Ait. [= Q. virginiana Miller], a white oak relative) are essentially identical. For similar reasons, Ørsted (1871) included a section Ilex in his subgenus Lepidobalanus (white oaks in a broad sense), while expanding this section to include evergreen North American white oaks (the sect./subsect. Virentes of Loudon, Trelease, Camus, etc.) On the other hand, the Himalayan Ilex oak Q. lanata was included in Ørsted's section Prinus of North American white oaks. The assumption that leaf texture can be used to assign species to higher taxonomic groups on a global scale supports Schwarz' largely artificial subgenera (and genera to some degree). Using the descriptions by Trelease, the Eurasian Ilex oaks would still fall in his subgenus Protobalanus, and the same is true for the descriptions in Nixon (1993) and the Flora of North America (Manos 1997).

Nixon's concept of a section Quercus including all white, Cerris and Ilex oaks primarily relies on the basal position of aborted ovules in these groups. Already de Candolle (1862b) noted this feature as being variable in different oak species, and Camus (1936-1938, p. 40f) emphasised that this trait is stable not only within a species, but also characterises groups of species (but see general descriptions in Menitsky 1984). Nixon also adopted Camus' concept of subgenus Cyclobalanopsis (aborted ovules always apical; but see general description provided by Huang et al. 1999). Apical abortive ovules, on the other hand, are found in most but not all subsections of sect. Erythrobalanus (the red oaks) and in the castanoid genera. 
Therefore, Nixon suggested that basal abortive ovules are a synapomorphy of his sect.

Quercus. Subsequent work has shown that the position of aborted ovules in the mature seeds of Quercus is the result of different developmental processes and less stable than originally assumed (Borgardt and Pigg 1999; Borgardt and Nixon 2003; Deng et al. 2008; Table 1). The only two classification schemes that recognised the same groups later recovered in molecular studies are those by Trelease (1924) and Menitsky (1984). Notably, these monographs were restricted to North American and Eurasian oaks, respectively. Therefore, they did not run the risk of creating artificial groups including morphologically similar but unrelated Old World and New World species.

Table 1: Different contributions of placenta and funiculus to the position of aborted ovules in mature seeds of Quercus. Information compiled from Borgardt and Pigg (1999), Borgardt and Nixon (2003), Deng (2007), Deng et al. (2008), and complemented by Min Deng (unpublished data).

\begin{tabular}{l|llllll}
\multicolumn{1}{c|}{ Section(s) } & $\begin{array}{l}\text { Quercus, } \\
\text { Ponticae, } \\
\text { Virentes }\end{array}$ & Lobatae & $\begin{array}{l}\text { Protobal- } \\
\text { anus }\end{array}$ & $\begin{array}{l}\text { Cyclobal- } \\
\text { anopsis }\end{array}$ & Cerris & Ilex \\
\hline $\begin{array}{l}\text { Position of } \\
\text { aborted } \\
\text { ovules }\end{array}$ & Basal & Apical & $\begin{array}{l}\text { Apical, } \\
\text { basal, } \\
\text { or lateral }\end{array}$ & Apical & $\begin{array}{l}\text { Apical, basal, } \\
\text { or lateral }\end{array}$ & $\begin{array}{l}\text { Basal or } \\
\text { lateral }\end{array}$ \\
Placenta & Sessile & Elongated & $?$ & Types I, III & Type II & $\begin{array}{l}\text { Types II, } \\
\text { III }\end{array}$ \\
Funiculus & Sessile & Sessile & $?$ & $\begin{array}{l}\text { Sessile or } \\
\text { elongated }\end{array}$ & $\begin{array}{l}\text { Sessile or } \\
\text { (compred }\end{array}$ & $\begin{array}{l}\text { Sessile or } \\
\text { elongated } \\
\text { Sessile or } \\
\text { elongated }\end{array}$ \\
\hline
\end{tabular}

Notes: Type I: apical/lateral aborted ovules by elongated placenta, Type II: by elongated funiculus, Type III: both elongated placenta and funiculus. Other Fagaceae (Castanea, Castanopsis, Lithocarpus, Trigonobalanus) have Types I \& III aborted ovules. All other Fagaceae have apical aborted ovules.

\section{Changing from morphology to molecules}

The first molecular phylogeny of Quercus including a comprehensive oak sample is the one of Manos et al. (2001) based on sequences of the nuclear ITS region and plastid RFLP data. While Manos et al.'s molecular phylogeny included only a limited sample of Old World species, it challenged the traditional views of Ørsted until Nixon. Instead, the intermediate and white oaks grouped with the red oaks, forming the 'New World Clade', but not with the Cerris and Ilex oaks. The latter formed an 'Old World Clade' that later would be shown to include the cycle-cup oaks (Manos et al. 2008). While the red oaks and cycle-cup oaks were resolved in well-supported and distinct clades within their respective subtrees, the situation 
appeared more complex for Camus' section Cerris (including a few Ilex oaks) and the white oaks (Manos et al. 2001). The lack of unambiguous support may be one reason, why morphologists and oak systematists did not readily implement the new evidence (e.g. Borgardt and Nixon 2003; le Hardÿ de Beaulieu and Lamant 2010; see also www.internationaloaksociety.org). The other reason is probably that the two new clades lacked compelling, unifying morphological traits.

Plastid gene regions commonly used in plant phylogenetics turned out to be less useful for inferring infrageneric and inter- to intraspecific relationships in oaks. This is mainly because the plastid genealogy is largely decoupled from taxonomy and substantially affected by geography (e.g. Neophytou et al. 2010; Neophytou et al. 2011; Simeone et al. 2016; Pham et al. 2017). Using genus- to family-level plastid data sets, even when combined with nuclear data, oaks are consistently recognised as a diphyletic group. This is best illustrated in Manos et al. (2008): one moderately supported main clade comprises the 'New World Clade' of oaks and Notholithocarpus, a monotypic Fagaceae genus of western North America; the other major clade comprises the Eurasian Fagaceae Castanea and Castanopsis, and the 'Old World Clade' of Quercus. The phenomenon is also seen in broadly sampled plastid data sets and can produce highly artificial molecular phylogenies (e.g. Xiang et al. 2014; Xing et al. 2014) as discussed in Grímsson et al. (2016). Nevertheless, all currently available plastid data reject the traditional subdivision into two subgenera Cyclobalanopsis and Quercus: the overall signal (e.g. Manos et al. 2008) is in line with the 'New World/Old World Clade' concept introduced by Oh \& Manos (2008).

In view of the problems encountered with plastid sequence data, oak molecular phylogenetics concentrated on nuclear-encoded sequence regions. Nine years after the study by Manos et al. (1999), the first ITS phylogeny was confirmed and supplemented by data from a single-copy nuclear gene region, the Crabs Claw (CRC) gene (Oh and Manos 2008). Denk \& Grimm (2010) provided an updated Fagaceae ITS tree including more than 900 individual sequences of oaks (including ca. 600 newly generated for western Eurasian species taking into account substantial intra-individual variation). Their data on the 5S intergenic spacer (over 900 sequences), a multicopy nuclear rDNA gene region not linked with the ITS region, supported three groups of western Eurasian oaks as originally conceived by Menitsky (1984). Hubert et al. (2014) compiled new data from six single-copy nuclear gene regions and combined the new data with ITS consensus sequences (based on Denk and Grimm 2010) and CRC sequence data (Oh and Manos 2008). Most recently, Hipp et al. (2015) showed a tree based on a large, 
bioRxiv preprint doi: https://doi.org/10.1101/168146; this version posted July $31,2017$. The copyright holder for this preprint (which was not certified by peer review) is the author/funder, who has granted bioRxiv a license to display the preprint in perpetuity. It is made available under aCC-BY-ND 4.0 International license.

nuclear reduced representation next-generation sequencing (RADseq) data set. All these data sets and analyses support the recognition of two, reciprocally monophyletic groups of oaks (Fig. 2) that can be formalised as two subgenera with eight phylogenetic lineages (Hubert et al. 2014; Hipp et al. 2015), accepted here as sections that match the morphological groups originally perceived by Trelease (1924) and Menitsky (1984):

- Subgenus Quercus, the 'New World clade' (Manos et al. 2001) or 'high-latitude clade' (Grímsson et al. 2015; Simeone et al. 2016), including

0 the North American intermediate oaks, section Protobalanus (= Trelease's subgenus of the same name);

o the western Eurasian-western North American disjunct section Ponticae;

o the North American "southern live oaks", section Virentes;

o all white oaks from North America (= Trelease's subgenus Leucobalanus) and Eurasia (= Menitsky's section Quercus), section Quercus; and

0 the North American red oaks, section Lobatae (= Trelease's subgenus Erythrobalanus).

- Subgenus Cerris, the exclusively Eurasian 'Old World clade' (or 'mid-latitude clade'), including

o the cycle-cup oaks of East Asia (including Malesia), section Cyclobalanopsis (former [sub]genus Cyclobalanopsis of Ørsted, Camus, Schwarz, Menitsky, and Nixon);

o the Ilex oaks, section Ilex (= Menitsky's subgenus Heterobalanus minus Q. suber); and

o the Cerris oaks, section Cerris (= Menitsky's section Cerris minus Q. alnifolia).

Figure 2 (next page): Revised sectional classification of oaks and diagnostic characters of lineages. The basic phylogenetic relationships of the six infrageneric groups of oaks are shown, formalised here as sections in two monophyletic subgenera, subgenus Cerris ('Old World' or 'midlatitude clade') and subgenus Quercus ('New World' or 'high-latitude clade'). Section-specific traits in bold; subgenus-diagnostic traits indicated at the respective branches of the schematic phylogenetic tree (Hubert et al. 2014; Hipp et al. 2015). Most traits are shared by more than one section of oaks including non-sister-lineages (normal font); they evolved convergently or are potentially plesiomorphic traits. Some are variable within a section as indicated by (semi-)proportional pie charts. Nonetheless, each section can be diagnosed by unique, unambiguous character suites. Note: 'yes' (green) and 'no' (red) refers to whether the mentioned trait is observed or not in members of the section, but should not be generally viewed as derived or ancestral. 


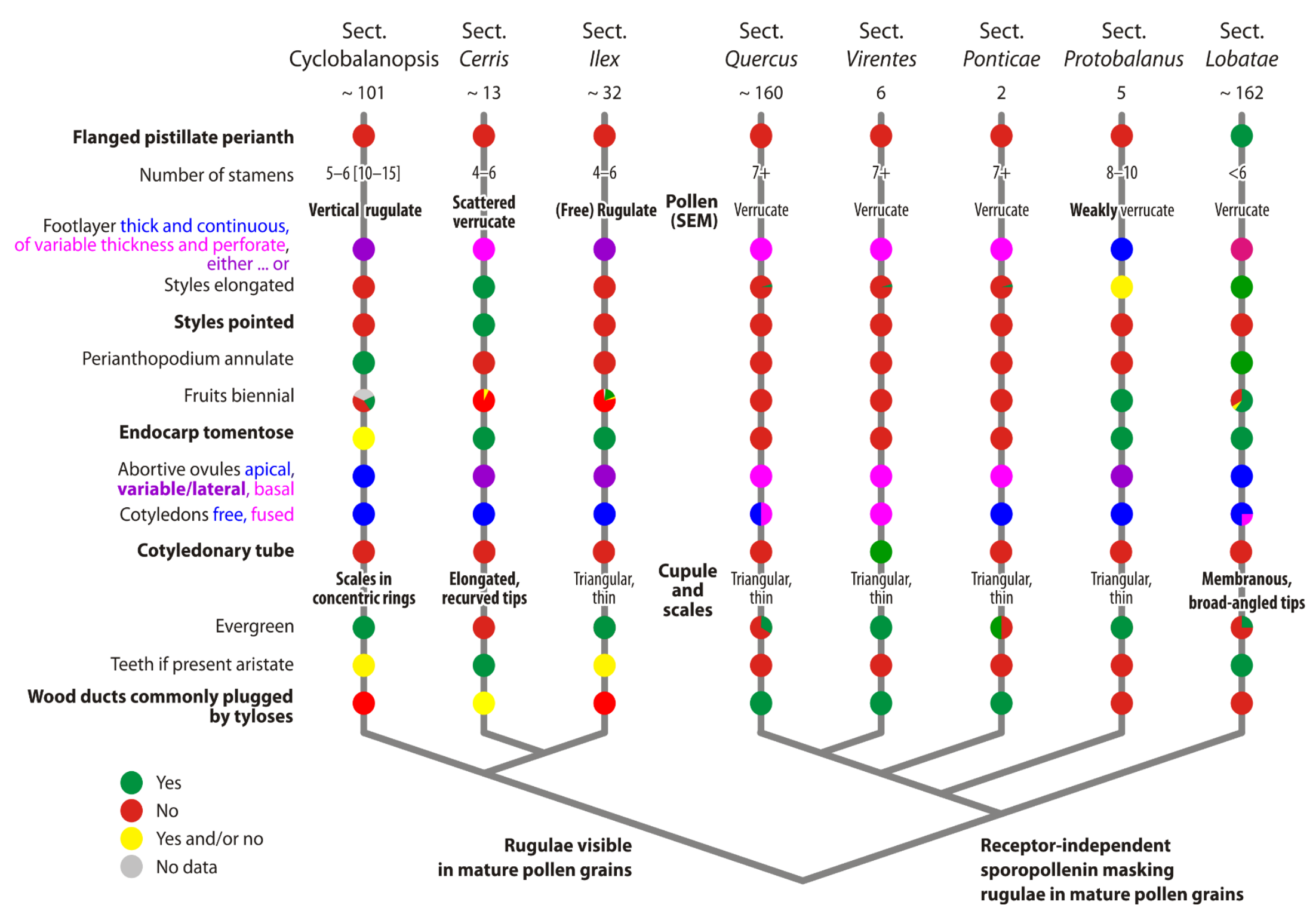




\section{Part B. Revised subgeneric and sectional classification of oaks}

The following information for diagnostic morphological characters for the recognised groups of oaks is based mostly on information provided in Trelease (1924), Camus (1936-1938, 1938-1939, 1952-1954), Schwarz (1936, 1937), Menitsky (1984), le Hardÿ de Beaulieu \& Lamant (2010), and the Floras of China (Huang et al. 1999) and North America (Flora of North America Editorial Commitee 1997). Information on pollen morphology is from Rowley et al. (1979), Solomon (1983a, 1983b), Rowley \& Claugher (1991), Rowley (1996), Rowley \& Gabarayeva (2004), Denk \& Grimm (2009), Makino et al. (2009), and Denk \& Tekleva (2014). Updated information on the position of aborted ovules and the relative contributions of placenta and funiculus to it is from Borgardt \& Nixon (2003), Deng et al. (2008), and Min Deng (unpublished data).

If no reference is provided, most monographers (Trelease 1924; Schwarz 1936; Camus 19361938; Schwarz 1937; Camus 1938-1939, 1952-1954; Menitsky 1984) agreed on a particular character. Trelease (1924) emphasised the importance of wood characters for delimitation of major groups of North American oaks. According to Trelease (1924), Menitsky (1984), and Akkemik and Yaman (2012) the type of wood porosity and presence or absence of tyloses plugging vessels of early-wood are clade-specific to some degree.

Group-specific traits are highlighted by italics (see also Fig. 2).

\section{Genus Quercus}

1753, Sp. P1., 1: 994.

Lectotype: Quercus robur L. (selected by Britton and Brown, Ill. Fl. N. U.S. ed. 2. 1: 616, 7 Jun 1913; confirmed by Green, in Sprague, Nom. Prop. Brit. Bot.: 189, Aug 1929)

Trees 20-30(-55) m high, or shrubs; monoecious, evergreen or deciduous; propagating from seeds (saplings) or, occasionally, vegetative propagation (ramets); bark smooth or deeply furrowed or scaly or papery, corky in some species; wood ring-porous or (semi) diffuse-porous, tyloses common in vessels of early-wood or rarely present; terminal buds spherical to ovoid, terete or angled, all scales imbricate; leaves spirally arranged, stipules deciduous and inconspicuous or sometimes retained until the end of the vegetative period; lamina chartaceous or coriaceous, lobed or unlobed, margin entire, dentate or dentate with bristle-like extensions; primary venation pinnate; secondary venation eucamptodromous, brochidodromous, craspedodromous, semicraspedodromous, or mixed; intersecondary veins 
present or absent; inflorescences unisexual in axils of leaves or bud scales, usually clustered at base of new growth; staminate inflorescences lax, racemose to spicate; pistillate inflorescence usually stiff, a simple spike, with terminal cupule and sometimes one to several sessile, lateral cupules; staminate flowers subsessile, in dichasial clusters of 1-3(-7) (section Cyclobalanopsis) or solitary; sepals connate, stamens (2-)6(-15), pistillodes reduced and replaced by a tuft of silky hairs; pollen monad, medium-sized or small (size categories according Hesse et al. 2009), 3-colp(or)ate, shape prolate, outline in polar view trilobate or rounded, in equatorial view elliptic to oval, tectate, columellate; pollen ornamentation (micro)rugulate, (micro) rugulate-perforate, or (micro)verrucate, (micro)verrucate-perforate; foot layer discontinuous or continuous, of even or uneven thickness; pistillate flower one per cupule, with 1-2 subtending bracts, sepals connate, (3-)6 (-9) lobed, either situated directly on the tip of the ovary or on the perianthopodium (stylopodium); carpels and styles 3-6, occasionally with staminodes, styles with a broad stigmatic surface on adaxial suture of style (less prominent in section Cyclobalanopsis); ovules pendent, anatropous or semi-anatropous; position of aborted ovules apical, basal, or lateral depending on whether or not the placenta and/or funiculus are secondarily elongated; fruit a one-seeded nut (acorn) with a proximal scar, fruit maturation annual or biennial, nut one per cup, round in cross-section, not winged, cotyledons free or fused; endocarp glabrous or tomentose; cup covering at least base of nut, with lamellate rings or scaly; scales imbricate and flattened or tuberculate, not or weakly to markedly reflexed; chromosome number $\mathbf{X}=12$. Around 400 species mostly in the Northern Hemisphere (Fig. 3).

\section{Subgenus Quercus}

Receptor-independent sporopollenin masking rugulae in mature pollen grains (Rowley and Claugher 1991; Rowley 1996).

\subsection{Section Protobalanus (intermediate oaks)}

Quercus section Protobalanus (Trelease) Schwarz, Notizbl. Bot. Gart. Berlin-Dahlem, 13/116: 21 (1936)

Quercus subgenus Protobalanus Trelease, in Standley, Contr. US Natl. Herb. 23:176 (1922). - Quercus section Protobalanus (Trelease) Camus, Les Chênes, 1: 157 (1938). - Quercus section Protobalanus (Trelease) Schwarz, Notizbl. Bot. Gart. Berlin-Dahlem, 13/116: 21 (1936) p.p. 
Type: Quercus chrysolepis Liebm. (Trelease, Proc. Natl. Acad. Sci. 2: 627, 1916; confirmed by Nixon, Ann. Sci. For. 50, suppl. 1: 32s, 1993)

Stamens 8-10, with apiculate apices (Trelease 1924); pollen ornamentation weakly verrucate, perforate (Denk and Grimm 2009); footlayer thick and continuous (Denk and Tekleva 2014); styles short to long, elliptic in cross-section; stigmata abruptly dilated; stigmatic surface extending adaxially along stylar suture (Trelease 1924; Manos 1997); fruit maturation biennial (Trelease 1924; Camus 1952-1954; Manos 1997); endocarp tomentose (Trelease 1924; Camus 1952-1954; Manos 1997); position of abortive ovules basal, lateral or apical, can be variable within a single plant (Manos 1997); cup scales triangular and fused at the base, thickened and compressed into rings, often tuberculate and obscured by glandular trichomes, with sharp angled tips; leaf dentitions spinose; wood diffuse porous, tyloses rarely present in vessels of early-wood (Trelease 1924).

Five species in southwestern North America and northwestern Mexico (Manos 1997).

\subsection{Section Ponticae}

Quercus section Ponticae Stefanoff., Ann. Univ. Sofia, ser. 5, 8: 53 (1930)

Quercus ser. Sadlerianae Trelease, Oaks of America: 111 (1924). - Quercus subsect. Ponticae Menitsky (Stefanoff) A.Camus, Bull. Soc. Bot. Fr., 81: 815 (1934). - Quercus ser. Ponticae Schwarz, Notizbl. Bot. Gart. Berlin-Dahlem, 13/116: 11 (1936).

Lectotype (here designated): Quercus pontica K.Koch.

Shrubs or small trees, rhizomatous; number of stamens mostly 6 (Trelease 1924; Camus 1952-1954); pollen ornamentation verrucate (Denk and Grimm 2009); footlayer of variable thickness and perforate (Denk and Tekleva 2014); staminate catkins up to $10 \mathrm{~cm}$ long; styles short, fused or free, elliptic in cross-section; stigmata abruptly or gradually dilated (Schwarz 1936); fruit maturation annual; endocarp glabrous; position of abortive ovules basal; cotyledons free; cup scales slightly tuberculate with sharp angled apices, occasionally with attenuated tips (Trelease 1924; Gagnidze et al. 2014); leaves evergreen or deciduous, chestnut-like, stipules large, persistent or early shed, number of secondary veins 10-15(-25), dentate, teeth simple or compound (in Q. pontica), sharply mucronate or with thread-like, curved upwards extension; leaf buds large, bud scales loosely attached (Trelease 1924; 
Schwarz 1936; Menitsky 1984); wood ring porous or diffuse porous, large vessels commonly plugged by tyloses.

Two species in mountainous areas of north-eastern Turkey and western Georgia

(Transcaucasia) and in western North America (northern-most California, southern-most

Oregon; Trelease 1924; Menitsky 1984; Gagnidze et al. 2014) (Fig. 3).

\subsection{Section Virentes}

Quercus section Virentes Loudon, Arbor. Frut. Brit., 3: 1918 (1838)

Quercus ser. Virentes Trelease, Oaks of America: 112 (1924)

Type: Quercus virens Aiton (=Q. virginiana Mill.)

Trees or rhizomatous shrubs; pollen ornamentation verrucate (Denk and Grimm 2009); footlayer of variable thickness and perforate (Denk and Tekleva 2014); styles short, fused or free, elliptic in cross-section; stigmata abruptly or gradually dilated (Schwarz 1936); fruit maturation annual; cup scales narrowly triangular, free or fused at the base, thinly keeled and barely tuberculate with sharp angled apices; leaves evergreen or subevergreen (Trelease 1924; Nixon and Muller 1997); wood diffuse porous, tyloses abundant in large vessels (Trelease 1924); cotyledons fused (de Candolle 1862a; Engelmann 1880); germinating seed with elongated radicle/epicotyl forming a tube (Nixon 2009); hypocotyl region produces a tuberous fusiform structure.

Ca. 7 species in south-eastern North America, Mexico, the West Indies (Cuba), and Central America (Muller 1961; Cavender-Bares et al. 2015) (Fig. 3).

\subsection{Section Quercus (white oaks s.str.)}

Quercus section Albae Loudon, Arbor. Frut. Brit., 3: 1730 (1838). - Quercus section Prinus Loudon, Arbor. Frut. Brit., 3: 1730 (1838). - Quercus section Robur Loudon, Arbor. Frut. Brit., 3: 1731 (1838). - Quercus section Virentes Loudon, Arbor. Frut. Brit., 3: 1730 (1838). - Quercus section Gallifera Spach, Hist. Nat. Veg., 11:170 (1842). - Quercus section Eulepidobalanus Oerst., Vidensk. Meddel. Naturhist. Foren. Kjøbenhavn 1866, $28: 65$ (1866-1867) p.p. - Quercus section Macrocarpae Oerst., Vidensk. Meddel. Naturhist. Foren. Kjøbenhavn 1866, 28: 68 (1866-1867). - Quercus section Diversipilosae C.K.Schneid., Handb. Laubholzk., 1: 208 (1906). - Quercus section Dentatae C.K.Schneid., Handb. Laubholzk., 1: 209 (1906). - Quercus section Mesobalanus A.Camus, Bull. Soc. Bot. Fr., 81: 815 (1934). - Quercus section Roburoides Schwarz, Notizbl. Bot. Gart. Berlin-Dahlem 13: 10 (1936). - Quercus section Robur Schwarz, Notizbl. Bot. Gart. Berlin-Dahlem 13: 12 (1936). - Quercus section Dascia (Kotschy) Schwarz, Notizbl. Bot. Gart. Berlin-Dahlem 13: 14 (1936). 
Stamens $\geq 7$ (Trelease 1924; Camus 1936-1938, 1938-1939); pollen ornamentation verrucate (Denk and Grimm 2009); footlayer of variable thickness and perforate (Denk and Tekleva 2014); styles short, fused or free, elliptic in cross-section; stigmata abruptly or gradually dilated; stigmatic surface extending adaxially along stylar suture (all authors; best illustrated in Schwarz 1936, fig. 1); fruit maturation annual; endocarp glabrous or nearly so; cotyledons free or fused; position of abortive ovules basal (de Candolle 1862b; confirmed/accepted by later authors), placenta and funiculus sessile; cup scales triangular, free or fused at the base, thickened, keeled and often tuberculate with sharp angled apices, occasionally with attenuated tips; leaf dentitions typically without bristle-like, aristate tips; wood ring porous, large vessels in (early-)wood commonly plugged by tyloses (Trelease 1924; see Akkemik and Yaman 2012).

Ca. 150 species in North America, Mexico, Central America, western Eurasia, East Asia, and North Africa (Nixon and Muller 1997).

\subsection{Section Lobatae (red oaks)}

Quercus section Lobatae Loudon, Hort. Brit., 385 (1830)

Quercus section Integrifoliae Loudon, Hort. Brit., 384 (1830) p.p. - Quercus section Mucronatae Loudon, Hort. Brit., 385 (1830) p.p. - Quercus section Rubrae Loudon, Arbor. Frut. Brit., 3: 1877 (1838; see also Loudon 1839). - Quercus section Nigrae Loudon, Arbor. Frut. Brit., 3: 1890 (1838; see also Loudon 1839). - Quercus section Phellos Loudon, Arbor. Frut. Brit., 3: 1894 (1838; see also Loudon 1839). - Quercus section Erythrobalanus Spach, Hist. veg. Phan., 11:160 (1842). - Quercus subgenus Erythrobalanus (Spach) Oerst., Vidensk. Meddel. Naturhist. Foren. Kjøbenhavn, $28: 70$ (1866-1867). - Erythrobalanus (Spach) O.Schwarz (as genus), Notizbl. Bot. Gart. Berlin-Dahlem 13: 8 (1936).

Lectotype: Quercus aquatica (Lam.) Walter (= Q. nigra L.) (Nixon, Ann. Sci. For. 50, suppl.1: 30s, 1993)

Pistillate perianth forming a characteristic flange (Schwarz 1936, fig. 1; Nixon 1993; Jensen 1997); number of stamens $\leq 6$ (Trelease 1924; Camus 1952-1954); pollen ornamentation verrucate (Denk and Grimm 2009); footlayer of variable thickness and perforate (Denk and Tekleva 2014); styles elongated, linear, outcurved, elliptic in cross-section; stigmata slightly dilated, spatulate to oblong; stigmatic surface extending adaxially along stylar suture (Trelease 1924); perianthopodium conical, often annulate (Trelease 1924); fruit maturation biennial, rarely annual (le Hardÿ de Beaulieu and Lamant 2010); endocarp tomentose; 
cotyledons free or sometimes basally fused; position of abortive ovules apical or rarely lateral to basal (de Candolle 1862b; Trelease 1924), placenta sessile or elongated, funiculus sessile; cupule fused with peduncle forming a 'connective piece' (compare Denk and Meller 2001) for Fagus), connective piece covered with small scales similar to those on the cupule; cup scales triangular and free, mostly thin, membranous and smooth with broadly angled tips; leaf teeth and lobes typically with bristle-like extensions, teeth reduced to bristles in entire or nearly entire leaves; wood ring-porous or semi ring-porous, late-wood markedly porous, tyloses in vessels of early-wood rarely present (Trelease 1924).

Ca. 120 species in North America, Mexico, Central America, and Colombia in South America (Jensen 1997).

\section{Subgenus Cerris}

Quercus subgenus Cerris Oerst., Vidensk. Meddel. Naturhist. Foren. Kjøbenhavn 1866, 28: 77 (1866-1867)

Lectotype (here designated): Quercus cerris L.

Rugulae visible in mature pollen grains or weakly masked (Solomon 1983a, b; Denk and Grimm 2009; Makino et al. 2009; Denk and Tekleva 2014).

\subsection{Section Cyclobalanopsis}

Quercus sect. Cyclobalanopsis (Oerst.) Benth. \& Hook. f., Gen. Plant. 3, 408 (1880) Cyclobalanopsis Oerst. (as genus), Vidensk. Meddel. Naturhist. Foren. Kjøbenhavn 1866, $28: 77$ (1866-1867), nom. conserv. - Quercus sect. Cyclobalanopsis (Oerst.) Benth. \& Hook. f., Gen. Plant. 3, 408 (1880). - Quercus subgenus Cyclobalanopsis (Oerst.) Schneider, Ill. Handb. Laubholzk. 1, 210 (1906).

Type: Quercus velutina Lindl. ex Wall., non Lam. (vide Farr and Zijlstra 2017)

Staminate flowers in groups of 1-3(-7) along inflorescence axis (Menitsky 1984; Nixon 1993); stamens 5-6 (Huang et al. 1999) to 10-15 (Ohwi 1965); pollen ornamentation vertical-rugulate (Denk and Grimm 2009); footlayer thick and continuous or of variable thickness and perforate (Denk and Tekleva 2014); styles short to very short $(<3 \mathrm{~mm}$ to $<$ $1 \mathrm{~mm})$, elliptic in cross-section; stigmata dilated, subcapitate; stigmatic surface not forming a 
prominent stigmatic groove (Camus 1936-1938; Menitsky 1984; Nixon 1993; Huang et al. 1999); perianthopodium annulate with 3-5 distinct rings (Schwarz 1936); fruit maturation annual or biennial (Camus 1936-1938; le Hardÿ de Beaulieu and Lamant 2010); endocarp tomentose ore rarely glabrous (Camus 1936-1938); cotyledons free; position of abortive ovules apical (Camus 1936-1938; Menitsky 1984) [note: according to Huang et al. (1999) the position is variable, but no details are provided in the species descriptions], placenta elongated reaching the apical part of the seed, where vascular bundles enter the seed and the aborted ovules, funiculus sessile or with short petiole; cupule with concentric lamellae; leaves evergreen; leaf dentitions with bristle-like extensions or not; wood diffuse porous, tyloses very rarely present in vessels of early-wood (Menitsky 1984).

Ca. 90 species in tropical and subtropical Asia including the southern Himalayas (Huang et al. 1999).

\subsection{Section Ilex}

Quercus section Ilex Loudon, Arbor. Frut. Brit., 3: 1899 (1838)

Quercus subgenus Heterobalanus Oerst., Vidensk. Meddel. Naturhist. Foren. Kjøbenhavn 1866, 28 : 69 (18661867). - Quercus subgenus Heterobalanus (Oerst.) Menitsky, Duby Azii, 89 (1984) [Oaks of Asia, 133, (2005)].

- Quercus section Heterobalanus (Oerst.) Menitsky, Duby Azii, 89 (1984) [Oaks of Asia, 134, (2005)]. Quercus subsection Ilex (Loudon) Guerke sensu Menitsky, Duby Azii, 97 (1984) [Oaks of Asia, 151, (2005)].

\section{Type: Quercus ilex L.}

Stamens 4 to 6 (Schwarz 1937); pollen ornamentation rugulate (Denk and Grimm 2009); footlayer thick and continuous or of variable thickness and perforate (Denk and Tekleva 2014); styles medium-long, apically gradually dilated, recurved, v-shaped in diameter; stigmata slightly subulate; stigmatic surface extending adaxially along stylar suture (Schwarz 1937; Menitsky 1984); fruit maturation annual or biennial (Camus 1936-1938, 1938-1939; Menitsky 1984; le Hardÿ de Beaulieu and Lamant 2010) [note that observations by Menitsky partly differ from those of Camus and le Hardÿ de Beaulieu and Lamant]; endocarp tomentose (Schwarz 1936; Camus 1936-1938; Schwarz 1937; Camus 1938-1939; Menitsky 1984); cotyledons free; position of the abortive ovules basal or lateral, placenta and funiculus sessile or elongated; cup scales triangular, free or fused at the base, mostly thin, membranous, often keeled and tuberculate with sharp angled apices, occasionally with slightly raised tips or narrowly triangular, well-articulated, thickened with elongated recurved tips (as in $Q$. 
alnifolia, Q. baronii, Q. coccifera, Q. dolicholepis); leaves evergreen, dentitions spinose or with bristle-like extensions; wood diffuse porous, tyloses rarely present in vessels of earlywood (Menitsky 1984).

Ca. 35 species in Eurasia and North Africa (Menitsky 1984; Denk and Grimm 2010; Deng et al. 2017).

\subsection{Section Cerris}

Quercus section Cerris Dumort., Florula Belgica: 15 (1829).

Quercus section Cerris Loudon, Arbor. Frut. Brit., 3: 1730 (1838). - Quercus section Eucerris Oerst., Vidensk. Meddel. Naturhist. Foren. Kjøbenhavn 1866, 28: 75, nom. illeg. (1867). - Quercus section Erythrobalanopsis Oerst., Vidensk. Meddel. Naturhist. Foren. Kjøbenhavn 1866, 28 : 76 (1867). - Quercus section Castaneifolia O.Schwarz, Feddes Repert., 33: 322 (1934). - Quercus section Vallonea O.Schwarz, Feddes Repert., 33: 322 (1934). - Quercus section Aegilops (Reichenb.) O.Schwarz, Notizbl. Bot. Gart. Berlin-Dahlem, 13/116: 19 (1936).

\section{Type: Quercus cerris L.}

Number of stamens 4-6; pollen ornamentation scattered verrucate (Denk and Grimm 2009); footlayer of variable thickness and perforate (Denk and Tekleva 2014); styles elongated, outcurved, pointed, v-shaped in diameter; stigmatic area linear; stigmatic surface extending adaxially along stylar suture; fruit maturation biennial, variable only in Q. suber (Camus 1936-1938; le Hardÿ de Beaulieu and Lamant 2010); endocarp tomentose (Camus 19361938); cotyledons free; position of abortive ovules basal, lateral or apical (de Candolle 1862b; Camus 1936-1938; Schwarz 1937; Menitsky 1984), placenta sessile, funiculus sessile or elongated; cup scales narrowly triangular, well-articulated, thickened and keeled with elongated, well-developed recurved tips; leaf dentitions typically with bristle-like extensions; wood (semi-)ring-porous, tyloses in vessels of early-wood present but not common (Trelease 1924; Akkemik and Yaman 2012).

Ca. 10-12 species in Eurasia and North Africa (Menitsky 1984). 


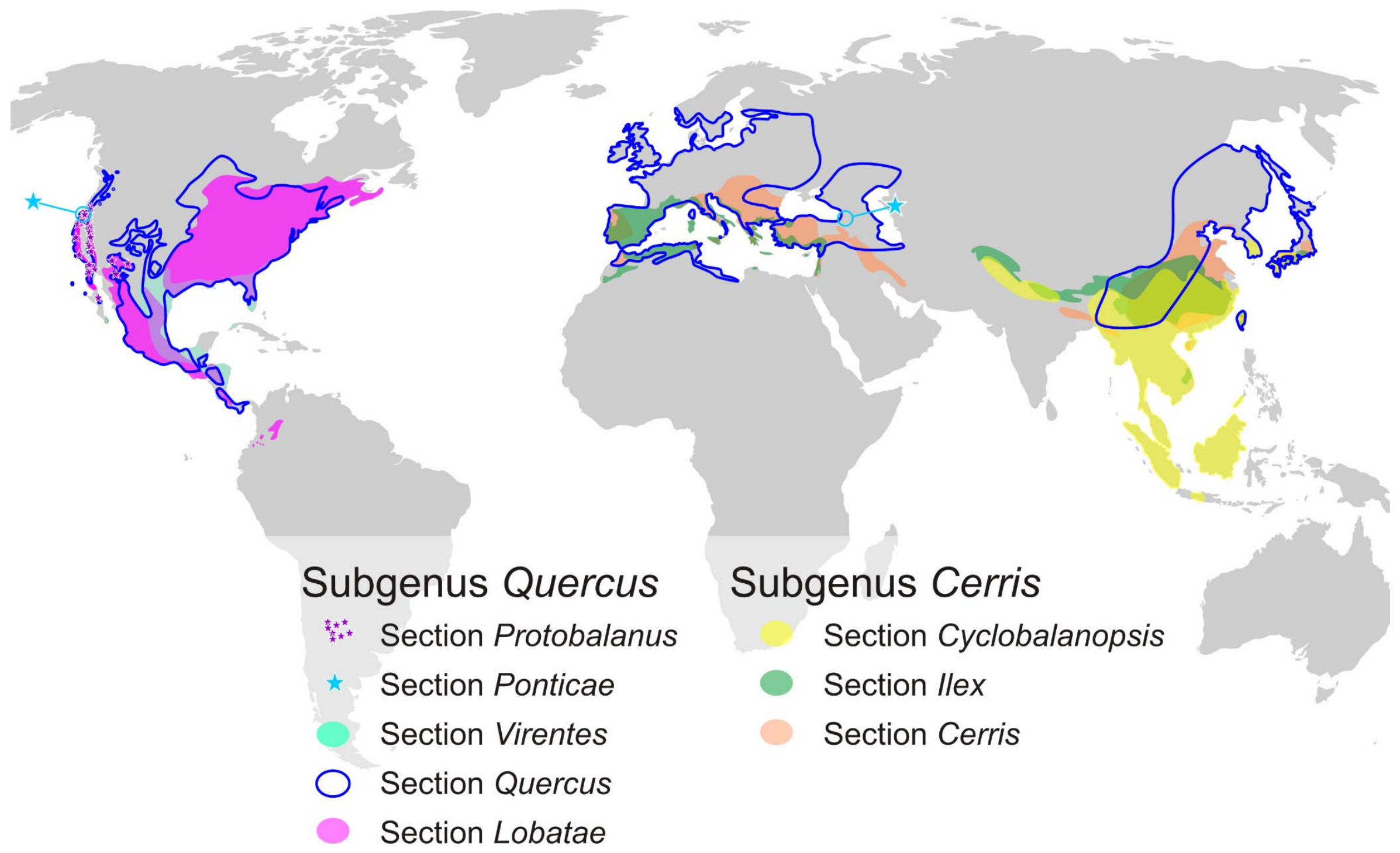

Figure 3: Geographic distribution of the eight sections of Quercus. Distribution data from Browicz and Zieliński (1982), Menitsky (1984), Costa Tenorio et al. (2001), Deng (2007), Fang et al. (2009), and Manos (2016) 


\section{Infrasectional classification: the big challenge}

The main challenge for oak systematics in the coming years will be a meaningful classification below the sectional rank. Nuclear-phylogenomic data (Hipp et al. 2015) within Quercus recover subclades that occur in well-defined biogeographic regions (e.g. western North America, eastern North America, western Eurasia, East Asia etc.), a sorting not so clear from traditional sequence data. Only very few New World-Old World disjuncts are recognised (e.g. section Ponticae; McVay et al. 2017). Ongoing phylogenomic work (Hipp et al. 2014; Hipp et al. 2015; McVay et al. 2017; Hipp et al. submitted) is beginning to reveal structure within the sections Lobatae and Quercus that corresponds to regional diversity within the Americas. Preliminary phylogenetic analyses suggested that the early evolutionary branches of Lobatae include many of the lobed-leaf species groups of North America (Hipp et al. 2015). The first branch, however, comprises the seven Californian taxa (Agrifoliae sensu Trelease), followed by various groups containing mostly temperate species that sort out into well-defined subclades. For section Quercus, analyses suggest some uncertainty at the base of the clade, specifically regarding the position of the Eurasian subclade. Previous morphologybased treatments of the Eurasian white oaks ('roburoids') suggested close affinities to certain eastern North American species, like Q. montana Willd. (series Prinoideae of Trelease), based on a similar (e.g. 'prinoid') leaf morphology (Axelrod 1983). In the most recent time calibrated tree (Hipp et al. submitted) the roburoids are nested within the white oak (s.str.) clade and diverged at around 25-30 Ma (Oligocene) from a North American, fully temperate clade including the type species of the section Quercus (Q. alba) and morphologically similar species such as Q. montana (see also Pearse and Hipp 2009; McVay et al. 2017). Dispersed pollen provide evidence for the presence of the white oak s.l. lineage (pollen types found today in sections Quercus and Ponticae but not Virentes) in the middle Eocene of western Greenland and the Baltic amber region of northern Europe (Grímsson et al. 2015; Grímsson et al. 2016; Eva-Maria Sadowski, unpublished data). Hence, the early radiation of this lineage involved the North Atlantic land bridge. Pollen and leaf fossil evidence from Eocene and Oligocene strata in East Asia further indicate migration from North America via the Bering land bridge. The expansion of this East Asian branch of white oaks (early roburoids) gave rise to the (modern) western Eurasian roburoids. This is in some agreement with the latest dated tree proposing a crown age of ca. 15-20 Ma for the roburoids. By that time, the final radiation within the North American white oaks (s.str.; section Quercus) might have been completed (Hipp et al. submitted). 
Lack of resolution using traditional sequence data, e.g. identical ITS variants found in North American and Eurasian white oaks, and the relative young inferred root (stem) and crown ages of the roburoids can be explained by recent episodic migration from North America to Europe across the North Atlantic land bridge in addition to probably (very) large population sizes of temperate (white) oaks. Ancient hybridisation between roburoids and section Ponticae has been identified as one possible source of potentially misleading phylogenetic data (McVay et al. 2017).

However, the current, partly preliminary results also indicate that (sub)sections/series recognised in the monographs of Trelease, Camus, and Menitsky do not always correspond to groups identified when using molecular sequence data. In some cases, the molecular-defined groups may seem counterintuitive. For example, the western Eurasian Ilex oaks Quercus alnifolia, Q. aucheri, Q. coccifera and Q. ilex are resolved as a monophyletic group (Denk and Grimm 2010; Hipp et al. 2015), but were placed into two subgenera and three sections by Schwarz (1936), and two sections and three subsections by Camus (1936-1938, 1938-1939) and Menitsky (1984) due to conspicuous differences in indumentum, leaf margin, and cup scales. Similar mismatches between traditional classification and DNA-based groups are encountered for all large infrageneric groups and will pose a major challenge when searching for morphological criteria to subdivide sections within oaks. For example, while it has long been noticed that characters of the indumentum of the abaxial leaf surface provide valuable information for species delimitation (Manos 1993; Nixon 2002; Tschan and Denk 2012; Deng et al. 2015, 2017), these characters appear to have evolved convergently in related and unrelated groups (Tschan and Denk 2012; Deng et al. 2017).

\section{Part C. Fossil record of the eight sections}

Section Protobalanus - In addition to pollen of section Lobatae, Grímsson et al. (2015) found dispersed pollen similar to pollen of section Protobalanus in middle Eocene deposits of western Greenland. Unambiguous leaf fossils and dispersed pollen of section Protobalanus are known from the latest Eocene-earliest Oligocene Florissant Formation (ca. $34 \mathrm{Ma}$; Bouchal et al. 2014). The section had a western and northern North American distribution during the Paleogene and became restricted to western North America during the Neogene.

Section Ponticae - Miocene and Pliocene leaf fossils assigned to Quercus pontica miocenica Kubát have traditionally been compared with the extant Q. pontica (e.g. Andreánszky 1959; 
Gagnidze et al. 2014). Presently, these fossils are included within the fossil-species Q. gigas Göppert, a fossil representative of section Cerris (Walther and Zastawniak 1991; Kvaček et al. 2002). These leaf remains and early Cenozoic fossils from Arctic regions (see Grímsson et al. 2016) are superficially similar to leaves of section Ponticae but lack the characteristic dentition of $Q$. pontica. Hence, there is currently no reliable fossil record of this section because chestnut-like foliage might have evolved in parallel in various modern and extinct lineages of Fagaceae or represents the primitive state within genus Quercus or subgenus Quercus.

Section Virentes-For similar reasons as outlined above for section Ponticae there is no reliable fossil record of this modern section.

Section Quercus_-Leaf fossils from middle Eocene deposits of Axel-Heiberg Island, Canadian Arctic (ca. $45 \mathrm{Ma}$; McIver and Basinger 1999) most likely belong to section Quercus. The leaf fossils are strikingly similar to the extant East Asian Quercus aliena Blume var. acutiserrata Maxim. ex Wenzig. From the roughly coeval Baltic amber of northern Europe, Crepet (1989) described in situ pollen of male flowers, which may represent section Quercus. Fagaceous remains from the Baltic amber are currently revised by Eva-Maria Sadowski, Göttingen, and may represent more than one section of Quercus. The leaf fossiltaxon Quercus kraskinensis Pavlyutkin from the early Oligocene of the Primorskii Region (Pavlyutkin 2015) is similar to the material from Axel-Heiberg Island and most likely belongs to section Quercus. The Paleogene radiation of the white oak lineage might have involved both the Bering and the North Atlantic land bridges. Lobed oaks of section Quercus are also known from the Oligocene of Central Asia and Northeast Asia (e.g. Krishtofovich et al. 1956; Tanai and Uemura 1994), and North America (Bouchal et al. 2014). Hence, the section had a scattered distribution during the Paleogene that included low, mid, and high latitudes. In the Neogene, section Quercus was widespread across the entire Northern Hemisphere (Borgardt and Pigg 1999).

Section Lobatae-Oldest fossils that can securely be assigned to section Lobatae are dispersed pollen from the middle Eocene of western Greenland (latest Lutetian to earliest Bartonian, 42-40 Ma). The pollen shows a sculpturing found today only in members of section Lobatae (Grímsson et al. 2015). A further record of entire-margined, lanceolate 
foliage with preserved epidermal structures from middle Eocene (48-38 Ma) deposits of Central Europe - described as Quercus subhercynica (Kvaček and Walther 1989) and originally assigned to section Lobatae - was subsequently transferred to the extinct genus Castaneophyllum, a fossil-genus for which morphological affinities to certain castaneoid genera have been established using leaf epidermal characteristics (Kvaček and Walther 2010 [2012]). For North America, Daghlian and Crepet (1983) described cups and acorns associated with lobate leaves from the Oligocene (Rupelian, ca. $30 \mathrm{Ma}$ ) Catahoula Formation in Texas (Quercus oligocenensis). Markedly similar leaf records from the early Oligocene of northeast Asia, Quercus sichotensis Ablaev et Gorovoj, Q. ussuriensis Krysh., Q. arsenjevii Ablaev et Gorovoj, and Q. kodairae Huzioka assigned to section Cerris (Tanai and Uemura 1994; Pavlyutkin 2015) clearly also belong to section Lobatae. Hence, the section had a midto high latitude northern hemispheric distribution during the Paleogene; during the Neogene it was present in Europe (Jähnichen 1966; Kovar-Eder and Meller 2003) and North America.

Section Cerris-The earliest unambiguous record of section Cerris, Quercus gracilis (Pavlyutkin) Pavlyutkin, comes from early Oligocene leaf fossils from the Russian Far East (Pavlyutkin et al. 2014). In western Eurasia, earliest evidence of section Cerris comes from dispersed pollen from late Oligocene/ early Miocene (ca. $23 \mathrm{Ma}$ ) deposits of Central Europe (Kmenta 2011). The section has a rich Neogene fossil record in Eurasia (e.g. Mai 1995; Song et al. 2000; Yabe 2008).

Section Ilex-The Paleogene record of Ilex oaks is so far limited to dispersed pollen from East Asia (Hainan Island, China, Changchang Formation, Lutetian-Bartonian, ca. $40 \mathrm{Ma}$; Hofmann 2010; Spicer et al. 2014) and Central Europe (Germany, Rupelian, ca. 33 Ma; Denk et al. 2012). From the Changchang Formation, Spicer et al. (2014) also reported leaf morphotypes (OTUs 68 and 71) that most likely belong to section Ilex. There is also leaf fossil evidence of section Ilex from 26 Ma strata in Tibet (Zhou Zhekun, personal communication). Section Ilex has a rich fossil record in Neogene deposits across Eurasia (e.g. Denk et al. 2017).

Section Cyclobalanopsis-Quercus paleocarpa (Manchester 1994) cupules and nuts from the Eocene (Lutetian, ca. $48 \mathrm{Ma}$ ) of western North America are possibly the oldest fossils belonging to section Cyclobalanopsis, but without preserved stigmas the assignment of these 
fruits remains ambiguous. Additionally, fossilised fruits of Cyclobalanopsis nathoi from the middle Eocene of Japan (Huzioka and Takahashi 1973) may belong to section Cyclobalanopsis based on the shape of nuts. Hofmann (2010) reported dispersed pollen grains from the middle Eocene of Hainan Island, China (Changchang Formation, Lutetian-Bartonian, 48-38 Ma; Spicer et al. 2014). From the Changchang Formation, Spicer et al. (2014) also reported leaf morphotypes (OTUs 61, 62 [partly], 63, 67) that most likely belong to section Cyclobalanopsis. From the Oligocene of south-western China, several fossil-species based on leaf impressions have been assigned to cycle cup oaks (Writing Group of Cenozoic Plants of China [WGCPC] 1978). Evidence for assignment to section Cyclobalanopsis is based on the number, arrangement, and course of secondary veins, the dentition, and the attenuate leaf apex (e.g. Q. parachampionii Cheu and Liu; Q. paraschottkyana Wang and Liu). This section has a Paleogene record in mid to low latitude East Asia and western North America, while it is restricted to Asia during the Neogene (e.g. Jia et al. 2015). No reliable records are known from Europe.

\section{Conclusion and outlook}

Recent molecular phylogenetic studies consistently suggest two major clades within oaks, one comprising three Old World groups (sections Cyclobalanopsis, Ilex, and Cerris), the other comprising three New World groups (sections Protobalanus, Virentes, and Lobatae,) and two northern hemispheric groups (sections Ponticae and Quercus). This is in contrast to the established view that Cyclobalanopsis oaks are sister to the remainder of the genus Quercus. The reason for this conflict is that morphological characters evolved convergently in all major groups of oaks and even outside oaks in other Fagaceae (e.g. concentric cupula rings). Important conserved morphological and diagnostic characters are pollen sculpturing and ultrastructure (Fig. 2).

Based on the new molecular and morphological evidence the infrageneric classification of Quercus is revised. A major challenge for future studies will be the molecular and morphological circumscription of infrasectional groups and their biogeographic and ecological characterisation. In this context, comparative morphological investigations of the seed ontogeny will be important to document the distribution of type I, II and III developmental pathways of aborted ovule positions (Table 1) across all sections. Some characters that have been described mainly on the basis of herbarium material, such as the annual or biennial mode of maturation, need to be reinvestigated in the field. In (fully) 
evergreen species of sections Ilex, Protobalanus, and Cyclobalanopsis, the fruiting twigs do not produce new growth in the second year after pollination (pseudo-annual maturation sensu Nixon 1997) and therefore may erroneously be interpreted as annual. In a number of highmountain species of section Ilex, maturation may take much longer than previously assumed, with time periods of up to three to four years between pollination and mature seeds (Min Deng, unpublished data). Considering the oak fossil record, it is noteworthy that Paleogene plant-bearing deposits from East Asia and the Far East have so far been understudied. Once recovered, this fossil record should contribute to a better understanding of the emergence of major groups within oaks.

\section{Acknowledgements}

We thank John McNeill for valuable comments. This work was supported by the Swedish Research Council (VR, grant to TD). GWG acknowledges financial support by the AMS Wien.

\section{Appendix}

The appendix is provided as a spread-sheet file (XLSX) including eight spread-sheets, uploaded as supplementary information, and containing the following information:

- an $<$ Overview $>$ of earlier and current systematic schemes for oaks (genera, subgenera, sections);

- $\quad$ characters used/reported by earlier systematicists (sheets $<$ Loudon $>$, <Trelease $>$, $<$ Camus $>,<$ Schwarz $>,<$ Menitsky $>,<90$ s $>$ ) extracted from the original literature;

- $\quad$ a comprehensive $<$ All species $>$ list of formerly and currently accepted species of oaks, compiled from the cited oak monographs and complemented by further data sources.

A copy of the appendix, which may be subject to future updates, will be included in an online archive provided for download at www.palaeogrimm.org/data/Dnk17_Appendix.zip.

Feel free to contact the authors for suggestions regarding (or errors found) in the appendix. 


\section{References}

Akkemik Ü, Yaman B (2012). Wood Anatomy of Eastern Mediterranean Species. Verlag Kessel, Remagen

Andreánszky G (1959). Die Flora der Sarmatischen Stufe in Ungarn. Akadémiai Kiadó, Budapest

Axelrod DI (1983) Biogeography of oaks in the Arcto-Tertiary Province. Ann Missouri Bot Gard 70:629-657

Bentham G, Hooker JD (1880). Genera Plantarum, Vol. 3. L. Reeve \& Co., Williams \& Norgate, London

Borgardt SJ, Nixon KC (2003) A comparative flower and fruit anatomical study of Quercus acutissima, a biennial-fruiting oak from the Cerris group (Fagaceae). Am J Bot 90:1567-1584

Borgardt SJ, Pigg KB (1999) Anatomical and developmental study of petrified Quercus (Fagaceae) fruits from the Middle Miocene, Yakima Canyon, Washington, USA. Am J Bot 86:307-325

Bouchal J, Zetter R, Grímsson F, Denk T (2014) Evolutionary trends and ecological differentiation in early Cenozoic Fagaceae of western North America. Am J Bot 101:1-18

Britton NL, Brown A (1913). An Illustrated Flora of Northern United States, Canada and British Possessions. Scribner \& Sons, New York

Browicz K, Zieliński J (1982). Chorology of Trees and Shrubs in South-West Asia and Adjacent Regions. Polish Scientific Publishers, Warsaw, Poznan

Camus A (1936-1938). Les Chênes. Monographie du genre Quercus. Tome I. Genre Quercus, sousgenre Cyclobalanopsis, sous-genre Euquercus (sections Cerris et Mesobalanus). Texte. Paul Lechevalier, Paris

Camus A (1938-1939). Les Chênes. Monographie du genre Quercus. Tome II. Genre Quercus, sousgenre Euquercus (sections Lepidobalanus et Macrobalanus). Texte. Paul Lechevalier, Paris

Camus A (1952-1954). Les Chênes : Monographie du genre Quercus. Tome III. Genre Quercus: sousgenre Euquercus (sections Protobalanus et Erythrobalanus) et genre Lithocarpus. Texte. Paul Lechevalier, Paris

Cavender-Bares J, Gonzalez-Rodriguez A, Eaton DAR, Hipp AL, Beulke A, Manos PS (2015) Phylogeny and biogeography of the American live oaks (Quercus subsection Virentes): A genomic and population genetics approach. Mol Ecol 24:3668-3687

Costa Tenorio M, Morla Juarista C, Sáinz Ollero H (2001). Los bosques Ibéricos. Una interpretación geobotánica. Planeta, Barcelona

Crepet WL (1989) History and implications of the early North American fossil record of Fagaceae. In: Crane PR, Blackmore S (eds) Evolution, systematics, and fossil history of the Hamamelida Vol 2: "higher" Hamamelidae. Systematic Association Special Volume 40B. Claredon, Oxford, p. 45-66

Daghlian CP, Crepet WL (1983) Oak catkins, leaves and fruits from the Oligocene Catahoula Formation and their evolutionary significance. Am J Bot 70:639-649

de Candolle A (1862a) Étude sur l'espèce á l'occasion d'une révision de la famille des Cupulifères. Arch Sci Phys Nat II 15:211-237, 326-365

de Candolle A (1862b) Note sur un charactère observé dans les fruits des chênes. Ann sci nat ser 4 $18: 49-58$

Deng M (2007) Anatomy, Taxonomy, Distribution and Phylogeny of Quercus Subg. Cyclobalanopsis (Oersted) Schneid. (Fagaceae). Ph.D. thesis, Kunming Institute of Botany, Chinese Academy of Sciences and Graduate School of Chinese Academy of Sciences, Beijing

Deng M, Hipp. A, Song Y-G, Li Q-S, Coombes A, Cotton A (2015) Leaf epidermal features of Quercus subgenus Cyclobalanopsis (Fagaceae) and their systematic significance. Bot J Linn Soc 176:224-259

Deng M, Jiang X-L, Song Y-G, Coombes A, Yang X-R, Xiong Y-S, Li Q-S (2017) Leaf epidermal features of Quercus Group Ilex (Fagaceae) and their application to species identification. Rev Palaeobot Palynol 237:10-36

Deng M, Zhou Z-K, Chen Y-Q, Sun W-B (2008) Systematic significance of the development and anatomy of flowers and fruit of Quercus schottkyana (subgenus Cyclobalanopsis: Fagaceae). Int J Plant Sci 169:1261-1277

Denk T, Grimm GW (2009) Significance of pollen characteristics for infrageneric classification and phylogeny in Quercus (Fagaceae). Int J Plant Sci 170:926-940 
Denk T, Grimm GW (2010) The oaks of western Eurasia: traditional classifications and evidence from two nuclear markers. Taxon 59:351-366

Denk T, Grímsson F, Zetter R (2012) Fagaceae from the early Oligocene of Central Europe: persisting New World and emerging Old World biogeographic links. Rev Palaeobot Palynol 169:7-20

Denk T, Meller B (2001) Systematic significance of the cupule/nut complex in living and fossil Fagus. Int J Plant Sci 162:869-897

Denk T, Tekleva MV (2014) Pollen morphology and ultrastructure of Quercus with focus on Group Ilex (= Quercus Subgenus Heterobalanus (Oerst.) Menitsky): implications for oak systematics and evolution. Grana 53:255-282

Denk T, Velitzelos D, Güner HT, Bouchal JM, Grímsson F, Grimm GW (2017) Taxonomy and palaeoecology of two widespread western Eurasian Neogene sclerophyllous oak species: Quercus drymeja Unger and Q. mediterranea Unger. Rev Palaeobot Palynol 241:98-128

Dumortier B-C (1829). Florula Belgica. J. Casterman, Tournai

Engelmann G (1880) The acorns and their germination. Trans Acad Sci St Louis 4:190-192

Fang J, Wang Z, Tang Z (2009). Atlas of Woody Plants in China. Volumes 1 to 3 and index. Higher Education Press, Beijing

Farr ER, Zijlstra G (2017) Index Nominum Genericorum (Plantarum). 1996+. http://botany.si.edu/ing/, last accessed 25/6/2017

Flora of China (2016) eFloras: Flora of China. http://www.efloras.org/flora_page.aspx?flora_id=2, last accessed 02/11/2016

Flora of North America Editorial Commitee (1997). Flora of North America north of Mexico. Vol. 3. Oxford University Press, New York

Gagnidze R, Urushadze T, Pietzarka U (2014). Quercus pontica Enzyklopädie der Holzgewächse: Handbuch und Atlas der Dendrologie 63. Erg. Lfg. 04/13. Wiley-VCH, Weinheim, p. 1-8

Govaerts R, Frodin DG (1998). World Checklist and Bibliography of Fagales (Betulaceae, Corylaceae, Fagaceae and Ticodendraceae). Royal Botanic Gardens, Kew

Grímsson F, Grimm GW, Zetter R, Denk T (2016) Cretaceous and Paleogene Fagaceae from North America and Greenland: evidence for a Late Cretaceous split between Fagus and the remaining Fagaceae. Acta Palaeobot 56:247-305

Grímsson F, Zetter R, Grimm GW, Krarup Pedersen G, Pedersen AK, Denk T (2015) Fagaceae pollen from the early Cenozoic of West Greenland: revisiting Engler's and Chaney's Arcto-Tertiary hypotheses. Plant Syst Evol 301:809-832

Hesse M, Halbritter H, Zetter R, Weber M, Buchner R, Frosch-Radivo A, Ulrich S (2009). Pollen Terminology - an Illustrated Handbook. Springer, Wien, New York

Hipp AL, Eaton DAR, Cavender-Bares J, Fitzek E, Nipper R, Manos PS (2014) A framework phylogeny of the American oak clade based on sequenced RAD data. PLoS ONE 9:e93975

Hipp AL, Manos P, McVay JD, Cavender-Bares J, González-Rodriguez A, Romero-Severson J, Hahn M, Brown BH, Budaitis B, Deng M, Grimm G, Fitzek E, Cronn R, Jennings TL, Avishai M, Simeone MC (2015). A phylogeny of the World's oaks. Botany 2015, Edmonton. Available at http://2015.botanyconference.org/engine/search/index.php?func=detail\&aid=1305

Hipp AL, Manos PS, González-Rodríguez A, Hahn M, Kaproth M, McVay JD, Valencia Avalos S, Cavender-Bares J (submitted) The American oaks exhibit convergent evolution in biogeography, climatic niche, and diversification rates. New Phytol

Hofmann C-C (2010). Microstructure of Fagaceae pollen from Austria (Paleocene/Eocene boundary) and Hainan Island (?middle Eocene)8th European Palaeobotany-Palynology Conference. Hungarian Natural History Museum, Budapest, p. 119

Huang C, Zhang Y, Bartholomew B (1999) Fagaceae. In: Wu Z-Y, Raven PH (eds) Flora of China 4 Cycadaceae through Fagaceae. Science Press and Missouri Botanical Garden Press, Beijing, St. Louis, p. 314-400

Hubert F, Grimm GW, Jousselin E, Berry V, Franc A, Kremer A (2014) Multiple nuclear genes stabilize the phylogenetic backbone of the genus Quercus. Syst Biodivers 12:405-423

Huzioka K, Takahashi E (1973) The Miocene flora of Shimonoseki, Southwest Honshu, Japan. Bull Nat Sci Mus 16:115-148 
Jähnichen H (1966) Morphologisch-anatomische Studien über strukturbietende, ganzrandige Eichenblätter des Subgenus Euquercus - Quercus lusatica n. sp. - im Tertiär Mitteleuropas. Monatsber Dtsch Akad Wiss Berlin 8:477-512

Jensen RJ (1997) Quercus Sect. Lobatae G. Don in J. C. Loudon, Hort. Brit. 385. 1830. In: Flora of North America Editorial Committee (ed) Flora of North America North of Mexico Vol 3. Missouri Botanical Garden Press, St. Louis, p. 447-468

Jia H, Jin P, Wu J, Wang Z, Sun B (2015) Quercus (subg. Cyclobalanopsis) leaf and cupule species in the late Miocene of eastern China and their paleoclimatic significance. Rev Palaeobot Palynol 219:132-146

Kmenta M (2011) Die Mikroflora der untermiozänen Fundstelle Altmittweida, Deutschland. M.Sc. thesis, University of Vienna, Vienna, Austria. http://othes.univie.ac.at/15964/

Kovar-Eder J, Meller B (2003) The plant assemblages from the main seam parting of the western subbasin of Oberdorf, N Voitsberg, Styria, Austria (Early Miocene). Cour Forschungsinst Senckenberg 241:281-311

Krishtofovich AN, Palibin IV, Shaparenko KK, Yarmolenko AV, Baykovskaya TN, Grubov VI, Iljinskaya IA (1956) Oligotsenovaya flora gory Ashutas v Kazakhstane (Oligocene flora of Ashutas Mount in Kazakhstan). Komarov Bot Inst Acad Sci SSSR Publ 145 Ser 8 Palaeobot 1:1-241 [in Russian]

Kvaček Z, Velitzelos D, Velitzelos E (2002). Late Miocene Flora of Vegora, Macedonia, N. Greece. Korali Publications, Athens

Kvaček Z, Walther H (1989) Palaeobotanical studies in Fagaceae of the European Tertiary. Plant Syst Evol 162:213-229

Kvaček Z, Walther H (2010 [2012]) European Tertiary Fagaceae with chinquapin-like foligae and leaf epidermal characteristics. Feddes Repert 121:248-267

le Hardÿ de Beaulieu A, Lamant T (2010). Guide illustré des Chênes. 2 vols. Edilens, Geer

Linné Cv (1753). Species Plantarum. Vol. 2. Laurentii Salvii, Stockholm

Loudon JC (1830). Loudon's Hortus Brittanicus. A. \& R. Spottiswoode, London

Loudon JC (1838). Arboretum et Fruticetum Brittanicum. Vol. III. Printed for the author by A. Spottiswoode, London

Loudon JC (1839) Part II. The Jussieuean Arrangement. In: Loudon JC (ed) Loudon's Hortus Brittanicus A new edition. A. Spottiswode, London, p. 491-704

Mai DH (1995). Tertiäre Vegetationsgeschichte Europas. Gustav Fischer Verlag, Jena, Stuttgart, New York

Makino M, Hayashi R, Takahara H (2009) Pollen morphology of the genus Quercus by scanning electron microscope. Sci Rep Kyoto Prefect Univ Life Environ Sci 61:53-81

Manchester SR (1994) Fruits and seeds of the Middle Eocene nut beds flora, Clarno Formation, Oregon. Palaeontogr Am 58:1-205

Manos PS (1993) Foliar trichome variation in Quercus section Protobalanus (Fagaceae). SIDA Contr Bot 15:391-403

Manos PS (1997) Quercus Sect. Protobalanus (Trelease) A.Camus. In: Flora of North America Editorial Committee (ed) Flora of North America North of Mexico Vol 3. Missouri Botanical Garden Press, St. Louis, p. 468ff

Manos PS (2016) Systematics and biogeography of the American oaks. Int Oak J 27:23-36

Manos PS, Cannon CH, Oh S-H (2008) Phylogenetic relationships and taxonomic status of the paleoendemic Fagaceae of Western North America: recognition of a new genus, Notholithocarpus. Madroño 55:181-190

Manos PS, Zhou ZK, Cannon CH (2001) Systematics of Fagaceae: Phylogenetic tests of reproductive trait evolution. Int J Plant Sci 162:1361-1379

McIver EE, Basinger JF (1999) Early Tertiary floral evolution in the Canadian High Arctic. Ann Missouri Bot Gard 86:523-545

McVay JD, Hipp AL, Manos PS (2017) A genetic legacy of introgression confounds phylogeny and biogeography in oaks. Proc R Soc B 284:20170300

Menitsky YL (1984). Duby Azii. Nauka, Leningrad [St. Petersburg] 
Menitsky YL (2005). Oaks of Asia [translated from the Russian original of 1984]. Science Publishers, Enfield, $\mathrm{NH}$

Muller CH (1961) The live oaks of the series Virentes. Am Midland Nat 65:17-39

Neophytou C, Aravanopoulos FA, Fink S, Dounavi A (2011) Interfertile oaks in an island environment: II. Limited hybridization Quercus alnifolia Poech and Q. coccifera L. in a mixed stand. Eur J For Res 130:623-635

Neophytou C, Dounavi A, Fink S, Aravanopoulos FA (2010) Interfertile oaks in an island environment: I. High nuclear genetic differentiation and high degree of chloroplast DNA sharing between Q. alnifolia and Q. coccifera in Cyprus. A multipopulation study. Eur J For Res 130:543555

Nixon KC (1993) Infrageneric classification of Quercus (Fagaceae) and typification of sectional names. Ann Sci For 50:25s-34s

Nixon KC (1997) Fagaceae. In: Flora of North America Editorial Committee (ed) Flora of North America North of Mexico. Oxford University Press, New York, p. 436-537

Nixon KC (2002) The oak biodiversity of California and adjacent regions. In: Standiford RB, McCreary D, Purcell KL (eds) Proceedings of the 5th Symposium on Oak Woodlands: Oaks in California's Changing Landscape. USDA Forest Service General Technical Report PSW-GTR-184. Pacific Southwest Research Station, San Diego,

Nixon KC, Muller CH (1997) Quercus Sect. Quercus Linneus. In: Flora of North America Editorial Committee (ed) Flora of North America North of Mexico Vol 3. Missouri Botanical Garden Press, St. Louis,

Oh S-H, Manos PS (2008) Molecular phylogenetics and cupule evolution in Fagaceae as inferred from nuclear CRABS CLAW sequences. Taxon 57:434-451

Ohwi J (1965). Flora of Japan (English ed., edited by F. G. Meyer and E. H. Walker). Smithsonian Institution, Washington, D.C.

Ørsted AS (1866-1867) Bidrag til egeslægtens systematik. Vidensk Medd naturhist Foren Kjöbenhavn 28:11-88

Ørsted AS (1871) Bidrag til Kundskab om Egefamilien. Kongl Danske Vidensk Selsk Biol Skr 5 naturvidensk math Afd 6:331-538

Pavlyutkin BI (2015) The genus Quercus (Fagaceae) in the early Oligocene flora of Kraskino, Primorskii Region. Paleontol J 49:668-676

Pavlyutkin BI, Chekryzhov IU, Petrenko TI (2014). Geology and floras of lower Oligocene in the Primorye. Dalnauka, Vladivostok

Pearse IS, Hipp AL (2009) Phylogenetic and trait similarity to a native species predict herbivory on non-native oaks. Proc Natl Acad Sci 106:18097-18102

Pham KK, Hipp AL, Manos PS, Cronn RC (2017) A time and a place for everything: phylogenetic history and geography as joint predictors of oak plastome phylogeny. Genome doi: 10.1139/gen2016-0191

Rowley JR (1996) Exine origin, development and structure in pteridophytes, gymnosperms and angiosperms. In: Jansonius J, McGregor DC (eds) Palynology, Principles and Applications. American Association of Stratigraphic Palynologists Foundation, Dallas, p. 443-462

Rowley JR, Claugher D (1991) Receptor-independent sporopollenin. Bot Acta 104:316-323

Rowley JR, Gabarayeva NI (2004) Microspore development in Quercus robur (Fagaceae). Rev Palaeobot Palynol 132:115-132

Rowley JR, Skvarla JJ, Ferguson IK, El-Gazhaly G (1979) Pollen wall fibrils lacking primary receptors for sporopollenin. In: Bailey GW (ed) Proceedings of the 37th Annual Meeting Electron Microscopy Society of America, San Antonio, TX, August 13-17, 1979. Claitor, Baton Rouge, p. 340-341

Schneider CK (1906). Illustriertes Handbuch der Laubholzkunde, Band 1. Gustav Fischer, Jena

Schwarz O (1934) In: Krause, K.: Beiträge zur Flora Kleinasiens, IV. Feddes Repert 33:321-328

Schwarz O (1936) Entwurf zu einem natürlichen System der Cupuliferen und der Gattung Quercus L. Notizbl Bot Gart Mus Berlin-Dahlem Bd. 13 Nr. 116:1-22

Schwarz O (1937). Monographie der Eichen Europas und des Mittelmeergebietes. Repertorium specierum nov. regni vegetabilis, Sonderbeihefte D. Selbstverlag Friedrich Fedde, Dahlem-Berlin 
bioRxiv preprint doi: https://doi.org/10.1101/168146; this version posted July 31, 2017. The copyright holder for this preprint (which was not certified by peer review) is the author/funder, who has granted bioRxiv a license to display the preprint in perpetuity. It is made available under aCC-BY-ND 4.0 International license.

Simeone MC, Grimm GW, Papini A, Vessella F, Cardoni S, Tordoni E, Piredda R, Franc A, Denk T (2016) Plastome data reveal multiple geographic origins of Quercus Group Ilex. PeerJ 4:e1897

Solomon AM (1983a) Pollen morphology and plant taxonomy of red oaks in eastern North America. Am J Bot 70:495-507

Solomon AM (1983b) Pollen morphology and plant taxonomy of white oaks in eastern North America. Am J Bot 70:481-492

Song SY, Krajewska K, Wang YF (2000) The first occurrence of the Quercus section Cerris Spach fruits in the Miocene of China. Acta Palaeobot 40:153-163

Spach E (1842). Histoire naturelle des végétaux. Phanerogames, vol. 11. Schneider \& Langrand, Paris

Spicer RA, Herman AB, Liao W, Spicer TEV, Kodrul TM, Yang J, Jin J (2014) Cool tropics in the Middle Eocene: Evidence from the Changchang Flora, Hainan Island, China. Palaeogeogr Palaeoclimatol Palaeoecol 412:1-16

Sprague TA (1929). International Botanical Congress Cambridge (England), 1930. Nomenclature Proposals by British Botanists. Wyman \& Sons, London

Standley PC (1922). Trees and Shrubs of Mexico. Contr US Natl Herb 23. Government Printing Office, Washington

Tanai T, Uemura K (1994) Lobed oak leaves from the Tertiary of East Asia with reference to the oak phytogeography of the northern hemisphere. Trans Proc Palaeontol Soc Japan 173:343-365

Trelease W (1916) The oaks of America. Proc Natl Acad Sci 2:626-629

Trelease W (1924). The American Oaks. Mem Natl Acad Sci 20. Washington Government Printing Office, Washington, D.C.

Tschan G, Denk T (2012) Trichome types, foliar indumentum and epicuticular wax in the Mediterranean gall oaks, Quercus subsection Galliferae (Fagaceae): implications for taxonomy, ecology and evolution. Bot J Linn Soc 139:611-644

Walther H, Zastawniak E (1991) Fagaceae from Sosnica and Malczyce (near Wrocłav, Poland). A revision of original materials by Goeppert 1852 and 1855 and a study of new collections. Acta Palaeobot 31:153-199

Writing Group of Cenozoic Plants of China (WGCPC) (1978). Cenozoic Plants from China. Fossil Plants of China 3. Science Press, Beijing [in Chinese]

Xiang X-G, Wang W, Li R-Q, Lin L, Liu Y, Zhou Z-K, Li Z-Y, Chen Z-D (2014) Large-scale phylogenetic analyses reveal fagalean diversification promoted by the interplay of diaspores and environments in the Paleogene. Perspect Plant Ecol Syst 16:101-110

Xing Y, Onstein RE, Carter RJ, Stadler T, Linder HP (2014) Fossils and large molecular phylogeny show that the evolution of species richness, generic diversity, and turnover rates are disconnected. Evolution 68:2821-2832

Yabe A (2008) Plant megafossil assemblage from the lower Miocene Ito-o Formation, Fukui Prefecture, Central Japan. Mem Fukui Prefect Dinosaur Mus 7:1-24 